\title{
JUAN LUIS VIVES ANTE LA FORTUNA ${ }^{1}$
}

\author{
MARCO ANTONIO CORONEL RAMOS
}

Universitat de València.Estudi General.

\begin{abstract}
Resumen
En el presente artículo se analiza la significación ética y política de los conceptos de fortuna y providencia en Juan Luis Vives. A través de ellos se materializan dos antropologías distintas encarnadas respectivamente en N. Maquiavelo y el propio J.L. Vives. Un punto de cruce entre ambas visiones de la realidad es el Lazarillo de Tormes en el que una fortuna dominada por el esfuerzo deriva en un éxito que no es más que una indignidad moral. En Vives la actitud razonable no es vivir dominando la fortuna, sino vivir por encima de la fortuna. Es en ese punto donde emerge la providencia como el cuidado amoroso que conduce al ser humano al conócete a ti mismo.
\end{abstract}

Palabras clave: Humanismo, literatura, Vives, Maquiavelo, Lazarillo.

\begin{abstract}
In the present paper we analyze the ethical and political significance of the concepts of fortune and providence in Juan Luis Vives. By means of these two concepts, two different anthropologies embodied respectively by N. Machiavelli and J.L. Vives himself take form. There exists a connection between these two visions about reality in the Lazarillo de Tormes, where an example of fortune dominated by effort becomes a successful life which only represents moral unworthiness. In Vives the reasonable attitude is not to live dominating fortune, but to live over fortune. It is at this point where the concept providence emerges as the loving care that leads human beings to know themselves.
\end{abstract}

Keywords: Humanism, literature, Vives, Machiavelli, Lazarillo.

\section{INTRODUCCIÓN}

Agustín de Hipona afirma en el capítulo I del libro V de La ciudad de Dios que la causa de la grandeza del Imperio Romano ni es fortuita ni fatal-nec fortuita est nec fatalis. Vives, en sus comentarios a esta obra, añade una nota al pasaje para disertar sobre la fatalidad en el mundo antiguo (Vives, 2000). Se pone entonces de relieve la complejidad de un campo semántico en el que se entremezclan con un alcance distinto y no siempre bien delimitado vocablos como casus, necessitas y fatum, además del de fortuna. Vives en la nota aludida trata de orientar el sentido de estos términos siguiendo el parecer heterogéneo de diversos autores. Empieza aludiendo al concepto platónico de

\footnotetext{
${ }^{1}$ Universidad de Valencia. Correo: marco.coronel@uv.es. Recibido: 31-01-2011. Aceptado: 07-03-2011.
} 
necesidad, una suerte de dictado fatal al que no pueden resistirse ni los mismos dioses. En contraste con este concepto escribe lo siguiente sobre la fortuna (2000: II, 492):

Por el contrario, los fenómenos que están bajo el influjo de los astros, son en ocasiones de una naturaleza tal que pueden ser evitados mediante la sabiduría, la diligencia y el trabajo. En este ámbito se sitúa la Fortuna. Pero lo que se desarrolla con causas determinadas y permanece inalterado, recibe el nombre de destino, que, sin embargo, no elimina la necesidad de una elección. Sin duda, hay mucho que está en nuestras manos: qué deseamos, qué emprendemos. Pero una vez emprendido algo, todo lo demás queda en manos del Destino.

Así pues, inspirándose en Platón (Rep. 617b-c), encierra bajo la noción de fortuna aquellas tendencias que, aunque ajenas a la voluntad, pueden ser controladas gracias a la sabiduría, el empeño y el esfuerzo -sapientia, industria y labor. Este será en cierto modo, como luego se verá, el pensamiento de Maquiavelo cuando trace su ideal de virtù como rienda o falsilla de la fortuna. Con todo, no será esta la noción más habitual de fortuna en el mundo antiguo. Más frecuentemente la fortuna será prefigurada como una tendencia o una causa ante la que poco puede hacer el empeño humano, y de ahí que el término pueda confundirse en determinadas acepciones con fatum, que, como recuerda Varrón (L.L. VI,52), define el dictado que determina el destino de las personas. En cualquier caso la fortuna no tiene como correlato griego el vocablo ajnavgkh, sino más bien el de tuvch. A ello se refiere Horacio cuando en sus odas describe la fortuna complacida en jugar con el hombre variando sus planes (III 29, 49-52).

La fortuna, por tanto, actúa sobre la existencia humana introduciendo el tamiz de lo eventual en medio de todos aquellos factores que determinan y delimitan la vida. A estos factores les acomoda el término de destino, que, como recuerda el propio Vives, no es incompatible con la obligación humana de elegir. Lo que sucede es que, tras la elección practicada, se desencadenaría una trama causal inexorable a la que se denomina precisamente destino. Desde esta lógica el hombre puede ser considerado responsable de su destino, porque éste pende de una elección previa. El valenciano, sin embargo, no se contenta en el pasaje que estamos comentando con exponer los argumentos platónicos, sino que analiza las diversas acepciones de estos vocablos en los autores griegos más destacados (2000: II, 492-4):

De todo esto [lo que dice Platón] ríese Epicuro y piensa que todos los acontecimientos se producen por circunstancias fortuitas, sin causa alguna, o bien, si hay algún motivo, no es otro sino la declinación del átomo. Los platónicos sitúan la fortuna en parte entre las causas ambiguas y que pueden comportarse de modo voluble, en parte también entre las oscuras e inciertas, sobre las cuales no puede aducirse razón por la que algo ha ocurrido de este modo que no sean las fácilmente variables o desconocidas. Abordan la cuestión de modo más claro Aristóteles (...) y los demás peripatéticos, entre los que Alejandro de Afrodisia escribe: Son fortuitos los hechos a la realización de los cuales no le ha sido preestablecido un fin por parte del agente. Por ejemplo, si alguien mientras cava para abonar la tierra encuentra un tesoro, esto es fortuna. Puesto que no lo hacía para encontrar oro: si a la vez la tierra se vuelve más fértil, consigue junto con lo fortuito lo que no lo es. Así, en las cosas no fortuitas hay un resultado que el agente había pretendido, mientras que en las fortuitas ese resultado está más allá de lo que se podría esperar o pensar. El vulgo llama a la fortuna ciega, temeraria, sin causa alguna, incierta, loca, irracional, tal como dice Pacuvio. Y ponen al destino entrelazado con la necesidad, y con la naturaleza tal que tiene derechos y poder no sólo sobre los demás dioses, sino incluso sobre el propio príncipe de todos ellos, el creador de las leyes de ese destino. (...) Hubo quienes querían que nada era fortuito, sino que todo era cierto, fijo e inmutable. Así Demócrito, Empédocles y Heráclito, a quienes siguieron muchos del pueblo, del mismo modo que muchísimos otros siguieron a Epicuro. (...) A menudo se emplea 'fortuna' con el sentido del propio 
destino y de la suerte de las cosas: cuando esa fortuna evoluciona conforme al deseo del alma se llama felicidad, y cuando lo hace en sentido contrario, infelicidad.

Quedan así planteados los tres conceptos sustanciales que venimos manejando en esta introducción: necesidad, fortuna y destino. Estos términos, como cabe suponerse y ya lo hemos indicado, no tienen siempre límites precisos, aunque, en líneas generales podría concluirse que mientras la necesidad es la causalidad inexorable, la fortuna es lo imprevisible de la vida y el destino el conjunto de consecuencias insoslayables de las decisiones. Los epicúreos no parecen estar de acuerdo con este esquema tal y como se refleja en su concepto de azar (Otón Sobrino 2000). Pero no es la visión epicúrea la que parece afectar al quehacer intelectual de Vives, sino más bien la que él denomina platónica, que alude a la fortuna como una causa ambigua, o las aristotélicas, para los que la fortuna son hechos que carecen de causa final. De hecho, Aristóteles en su Physica (195b-198a) explica que, junto a las causas, existe el azar o aujtovmaton -casus en latíny la tuvch -fortuna. Ambos términos aluden a acontecimientos excepcionales, pero el azar afectaría a las cosas naturales mientras que la fortuna atañe específicamente a la vida humana (Met. 1070a). Azar y fortuna remiten en bloque a acontecimientos contingentes opuestos al destino, que rige lo predeterminado.

Pero junto a estas definiciones cultas estos vocablos tienen también un sentido más común que es en el que sus límites más se difuminan. Vives no elude estas acepciones y se remite al vulgo para no dejar de considerar la fortuna como algo parecido a la necesidad o, más en concreto, al curso feliz o desgraciado que toman inesperada e involuntariamente los acontecimientos humanos. Este sentido más común de fortuna reposa sobre un cierto sincretismo entre fortuna y destino.

Teniendo presente lo dicho, puede concluirse que Vives, como se pondrá de relieve en este trabajo, elabora un concepto propio de fortuna en el que se entremezclan tres tradiciones distintas: (1) la reflexión filosófica que la define como resultado inesperado, inmotivado o insólito de los acontecimientos; (2) el sentido popular que habla de buena o mala fortuna según el efecto de esos giros involuntarios que toman los sucesos de la vida; y (3) la tradición cristiana que o bien identifica la fortuna con la providencia o bien desprecia la fortuna como desconfianza en la providencia. En el primer sentido la fortuna parece actuar al margen de toda causa final, en el segundo la fortuna se identifica con la suerte que corresponde a cada individuo en cada momento concreto; en el tercero la fortuna puede ser una especie de increencia.

\section{LA FORTUNA VIVESIANA.}

En cierto modo las tres tradiciones que confluyen en Vives al tratar de la fortuna se inspiran en el De Providentia de Séneca. Podría decirse que el valenciano ha cristianizado las advertencias que hace el autor latino para que, en vez de vivir con desesperación los golpes de la fortuna, se los asuma como resultado de la racionalidad que rige el universo. En efecto, el sabio y el bueno serían educados en la virtud gracias a esos sucesos. Séneca, en concreto, prefigura la fortuna como una fuerza en manos del destino para formar y forjar al sabio. En este sentido queda en suspenso el rasgo 
positivo o negativo de todo aquello que dependa de la fortuna, ya que, sobre la dicha o la desdicha, resalta el bien que le reporta al sabio. Así considerada, la fortuna no es una fuerza ciega, sino un instrumento de la providencia.

Concretamente la obra comienza remitiéndose a una pregunta que Lucilio habría hecho al propio Séneca. Lucilio, con palabras que tal vez el mismo Leibniz firmaría en su Teodicea ${ }^{2}$, se plantea cómo es posible conciliar la providencia con la realidad dañina que pueden padecer los hombres buenos $(\mathrm{I}, 1)$. El maestro considerará que “a esto se contestaría con mayor propiedad a lo largo de un tratado, al probar que la providencia preside el universo y que un dios se interesa por nosotros" $(\mathrm{I}, 1)^{3}$. La racionalidad del logos que rige el universo es la que da cuerpo al postulado de una providencia que cuida de los hombres. El dios aludido no es otra cosa que la ley de la naturaleza (Veyne 1995: 216) o, si se quiere, del propio logos.

Véase cómo en cierta manera se sincretizan las nociones de destino y fortuna: el destino cuida de los seres humanos y usa a la fortuna para fortalecer al hombre. En consecuencia, hay una armonía entre todo lo que existe que transforma todo azar en un plan trazado para que el hombre crezca en la virtud. No se olvide que el vocablo fortuna se refiere específicamente a la vida humana. Se justifica con estos argumentos que Séneca plantee su obra como una defensa de los dioses -causam deorum agam- (I,1), es decir, como defensa del orden de las cosas (I,2-4). Desde estos presupuestos el autor romano no se cree en la necesidad de explicar qué es la providencia o si ésta existe, sino que acude directamente a defenderla de las quejas de Lucilio (I,4). Por eso su objetivo es claro $(\mathrm{I}, 5)$ :

Volveré a congraciarte con los dioses, excelentes para los excelentes. Pues, la naturaleza no tolera que nunca lo bueno perjudique a lo bueno; entre los hombres buenos y los dioses hay amistad, pues la virtud la facilita. ¿Amistad digo? Más aún, confianza y semejanza, puesto que en realidad el hombre bueno sólo por su duración es distinto al dios; discípulo como es suyo e imitador y legítima descendencia, a la que aquel progenitor, recaudador nada blando de virtudes, educa con gran rigor, tal como los padres severos.

Aparece ya en esta cita otro de los términos que serán importantes en nuestro trabajo: la virtud entendida de diferentes maneras en el siglo XVI. La concepción de Vives se acerca a la aquí manifestada por Séneca que, por ello, manifiesta que la adversidad es una escuela para formar al hombre en la virtud. Lo dice siguiendo el modelo de los padres con los hijos (I,6):

Que esto mismo te quede claro con respecto al dios: no tiene al hombre bueno en la molicie, lo pone a prueba, lo endurece, lo prepara para sí.

En realidad al hombre bueno no le pasa nada malo, porque bueno y malo son términos contrarios y no se dan juntos (II,1) La explicación de esta afirmación es la siguiente (II,2):

Y no digo «no las siente» [las adversidades] sino «las vence» e incluso se alza, por lo demás tranquilo y calmo, contra las que lo acometen. Todas las adversidades las toma como entrenamientos.

\footnotetext{
${ }^{2}$ Sería una Teodicea limitada al sabio o, como dice P. Veyne (1995: 216), al justo.

${ }^{3}$ Las traducciones están tomada de la edición de J. Mariné Isidro (Séneca, 2000).
} 
Pone entonces el ejemplo de los atletas, que quieren luchar con los fuertes y en las peores circunstancias para curtirse (II, 3).Esta imagen tendrá mucho recorrido en el cristianismo desde que Pablo la utilizara ${ }^{4}$. La conclusión de Séneca es clara (II,4):

Se marchita sin oponente la virtud: se ve cuánta es su grandeza y cuánto su poder en el momento en que muestra de qué es capaz con su resistencia. Conviene que sepas que los hombres buenos deben hacer lo mismo, de modo que no se espanten ante circunstancias duras y difíciles y no se quejen del destino, sino que den por bueno cuanto les ocurra, lo vuelvan bueno. Lo importante no es qué soportas, sino de qué manera?

Se relativiza así los vaivenes de la fortuna, cosa que tanto gustará hacer a Vives incluso en los momentos tan dramáticos que le tocó vivir. La realidad de esta relativización es paladina (III, 1):

Pero ya cuando avance mi discurso mostraré hasta qué punto no son desgracias las que lo parecen: ahora afirmo que ésas que tú llamas amargas, adversas y abominables son provechosas primero a quienes les suceden y luego a la totalidad, de la que los dioses se cuidan más que de cada uno; tras esto, que suceden a quienes las desean y serían malditos si las rechazaran. A esto añadiré que transcurren así por el destino y ocurren a los buenos por la misma regla por la que son buenos. Luego te convenceré de que nunca compadezcas a un hombre bueno: pues puede ser llamado infeliz, pero no puede serlo.

La desdicha no depende, pues, de las vivencias, sino del modo de afrontarlas. Recuerda entonces el estoico latino una frase de un amigo suyo, el filósofo cínico llamada cínico (III, 3): Nada me parece más desdichado que uno al que nunca le ha ocurrido ninguna contrariedad.

Y pone el ejemplo del gladiador (III, 4):

El gladiador considera una deshonra verse enfrentado a un inferior y sabe que es vencido sin gloria aquél que es vencido sin peligro. Igual suele la suerte: se busca a los más esforzados como oponentes, a otros los da de lado con aversión.

No puede ser más explícito (IV, 1$)$ :

La felicidad va a parar a la plebe y a los de natural despreciable: por el contrario, subyugar desastres y terrores humanos es propio del grande hombre. Ser siempre dichoso y pasar la vida sin dentelladas en el espíritu es, de cierto, desconocer el otro lado de la naturaleza. Eres un gran hombre: pero ¿cómo lo sé, si la suerte no te da ocasión de demostrar tu valor?

La razón de todo ello tiene raigambre socrática (IV, 3):

Pues para el conocimiento de uno mismo es preciso pasar alguna prueba: nadie ha advertido de qué era capaz si no es intentándolo.

En el conócete-a-ti-mismo reside la importancia de la fortuna. La providencia la usa para labrar al hombre desde la racionalidad de la que nace el sabio. Es más, el hombre -afirma el autor cordobés- no puede evitar estas cosas malas, pero precisamente por ello son superiores a los propios dioses (VI, 6):

Pero nos caen encima muchas penalidades horrorosas, difíciles de tolerar.' Puesto que no podía yo sustraeros a ellas, armé vuestros ánimos contra todas ellas: soportadlas serenamente. Esto es en lo que aventajáis al dios: él está más allá del sufrimiento de las desgracias, vosotros por encima del sufrimien-

\footnotetext{
${ }^{4}$ 1Cor 9, 24-6: ¿No sabéis que en el estadio todos los corredores cubren la carrera, aunque uno solo se lleva el premio? Pues corred así: para ganar. Pero un atleta se impone toda clase de privaciones; ellos para ganar una corona que se marchita; nosotros, en cambio, una que no se marchita. Por eso corro yo, pero no al azar; lucho, pero no contra el aire; sino que golpeo mi cuerpo y lo someto, no sea que, habiendo predicado a otros, quede yo descalificado.
} 
to. Menospreciad la pobreza: nadie vive tan pobre como ha nacido. Menospreciad el dolor: o se destruye o destruye. Menospreciad la muerte: o bien os da fin o bien os cambia de lugar. Menospreciad la suerte: no le he dado ningún venablo con el que pudiera malherir el espíritu.

En consecuencia, estos son los pensamientos que están en la raíz de la concepción vivesiana de la fortuna. Así se demuestra, por ejemplo, en la conversación que Vives mantuvo con la reina Catalina. La conclusión de la charla es que la vida es una carrera -imagen senequista y paulina -como se ha visto- en la que necesariamente hay prosperidad y adversidad. No hay, por consiguiente, vida sin fortuna, es decir, sin el despliegue ambivalente de dicha y desdicha sin las cuales se hace difícil la maduración humana, que, en boca de Séneca y Vives, se remite al mencionado conócete-a-ti-mismo. He aquí cómo el valenciano le relata a su amigo Cranevelt la mencionada conversación (Jiménez Delgado 1978: 342):

Y sin embargo, a ratos mantenía conversaciones de filosofía con la reina. Confieso no haber visto nada tan puro ni tan cristiano como su alma. Últimamente cuando íbamos en barca a un monasterio de sagradas vírgenes para los divinos oficios, recayó la conversación sobre la prosperidad y la adversidad de la presente vida. Ella me dijo: "Si fuera posible, yo desearía una vida mezclada y moderada de las dos cosas. No querría sólo adversidades, pero tampoco sólo prosperidad. Y si fuera preciso desear una de las dos cosas, preferiría que todo me sucediera áspero y desabrido, que no de todo muy feliz; pues me parece que los hombres desgraciados necesitan consuelo, los que rebosan en felicidad, cabeza". ¿Quién no respetará y se rendirá de admiración ante un pecho tan noble? Así de ella y de su marido tengo muchas palabras pronunciadas en otras ocasiones, muchas de las cuales las daré a conocer a su tiempo.

Las palabras de la reina y la opinión de Vives que subyace en ellas se explican mejor desde Séneca. Y esa explicación no es otra que el argumento de la fortuna como herramienta bien en manos de la racionalidad del logos -como diría Séneca- o bien de Dios -tal y como afirmará Vives. Este pensamiento sitúa las adversidades en un correcto lugar: el de aprender la vida. Este pensamiento era compartido no sólo por la reina Catalina, sino por otros humanistas amigos de Vives como G. Budé, que escribe el 2 de mayo de 1520 a nuestro valenciano asintiendo con él en que me gusta aquello de que hay que guardarse del montón de los afortunados (Jiménez Delgado, 1978: 180). Ese montón de afortunados son aquellos que parecen que siempre viven y gozan de los bienes. Hay que guardarse de ellos porque carecen del aprendizaje que hace al ser humano humilde y verdaderamente humano. Por ello en el escrito que dedica a la Princesa María, hija de la reina Catalina, titulado Escolta del alma escribe lo siguiente (Riber 1992: I, 1184s):

54 Fortuna nimis blanda, hamata (La fortuna demasiado risueña trae anzuelo). Dice Publio Siro en sus composiciones mímicas: La fortuna, cuando halaga, lo hace con propósitos capciosos. La fortuna es la Divina Providencia. Con todo, esta empresa nos advierte que no nos dejemos soliviantar ni confiar en el bienestar físico ni en la acumulación de las riquezas. Estas cosas suelen entenderse con el nombre de fortuna. Dios no nos engaña. Nosotros nos engañamos a nosotros mismos con el uso necio de las cosas.

55. Fortuna fallacior quo blandior (Tanto más falaz es la fortuna cuanto más lisonjera) Esta empresa yo la había dado para el gobierno por su espíritu al cardenal Croy; pero más que empresa heráldica fue vaticinio, pues habiéndose la fortuna volcado con inaudita generosidad en su halda y en la de su tío, el señor de Chièvres, inesperada y repentinamente los hundió a los dos, pero al cardenal, muy verde aún, a los veintidós años.

56. Stabilissima fortuna stultissima (La fortuna más estable es la más necia) Dice el mismo Publio Siro: A aquel a quien la fortuna mima demasiado, le hace necio. En efecto, le retira el seso, y con tantos éxitos y 
resultados felices se insolenta el espíritu humano, por manera que ya ni puede soportar a los otros ni a sí mismo. Recuerdo que tu madre, esta santa mujer, me dijo un día que volvíamos en barca de Syon a Richemond, que ella prefería una fortuna meridiana, comedida, que otra que fuese o muy áspera o muy blanda; y que si se viera en el caso de elegir una, u otra de estas dos, escogería primero la más sañuda que la más risueña, porque a los más desventurados no les falta consuelo, mientras que a los más afortunados les falta seso. Estas manifestaciones de un pecho sabio y recatado yo las divulgué y las hice conocer de muchos en esta ciudad y comarca de Brujas.

Vives previene a la princesa de las situaciones dichosas continuadas, porque a su juicio es un anzuelo que impide atesorar la enseñanza necesaria para vivir en la virtud. La fortuna así vista es una herramienta en manos de la providencia. El valenciano sabía ciertamente de lo que hablaba, porque en su vida apuró hasta el extremo la mala fortuna. Las desgracias le perseguirán a lo largo de toda su existencia: desdichas familiares, penuria económica, dificultades editoriales, etc. Por eso escribe lo siguiente a su gran amigo Cranevelt el 10 de mayo de 1523 (Jiménez Delgado 1978, 314): “Pero pesa sobre mí un cierto infortunio, que me cierra el paso a toda clase de consuelos y me hostiga más cruelmente sin lenitivo alguno".

Con esta frase describe lo que fue una constante: el desamparo y la dependencia de circunstancias que escapaban a su control. La razón más conocida de este infortunio es la suerte adversa de su familia, que él describe al mismo interlocutor el 4 de enero de 1523 (Jiménez Delgado, 1978, 289s):

He sabido que el único de mis hermanos había muerto el día de San Juan Evangelista; pero la suerte no contenta con este golpe, me dicen que mi padre está enfermo de mucha gravedad y que se muere con muy pocas esperanzas; que han entablado un pleito muy serio y con gran saña contra nuestros bienes; que sobreviven tres hermanas mías, pobres y menores de edad. ¡Siempre tengo que comunicarte alguna queja de los hados! ¡Jamás una noticia alegre! ¿Por ventura obran así con tan continuas desventuras para que algún día puedan serme objeto de desprecio? Ni me es conveniente hablar mal de ellos ni tengo tiempo para ello. Y sabiendo que es ésta su naturaleza, llevemos con menos disgusto lo que no puede ser de otro modo. Con estas noticias aumentó mi angustia y la inquietud de mi espíritu, pues estoy pendiente de las cosas de España y no me atrevo a tomar una resolución definitiva para el futuro. No sé si en estas circunstancias es conveniente que vaya allí o que me quede; si les es del todo necesaria mi presencia, no lo sé; de forma que no me queda lugar ni para reflexionar. ¡Tan atados nos tiene la condición de los acontecimientos! (....) Ciertamente, si la Fortuna pudiera hacer a alguno miserable, tiempo ha que a nadie lo hubiera hecho más miserable que a mí. Pero ésta es la deuda que tenemos con la Filosofía, que ella, cruel y despiadada, emplea todo su poder contra nosotros, después que nosotros nos hemos entregado por entero a ella, para que nos formara y nos defendiera.

Como cabe suponer, las desgracias familiares de Vives se deben a los procesos incoados por judaísmo (Pinta Llorente-De Palacio: 1965ss; García, 1987). Todo eso hace que no sepa qué decisión tomar sobre si acudir a Alcalá donde había sido invitado a ocupar la cátedra vacante desde el fallecimiento de Nebrija. En esta carta, está hablando más del destino que de la fortuna, un destino que exige una elección previa de la que se derivará toda una serie de consecuencias que ya no están en sus manos. Sobre todo ello se manifiesta como sigue (Jiménez Delgado, 1978: 298):

De allí [de España] me llaman ahora de nuevo por carta; sin embargo, me retraen los gastos; me espanta el peligro. Imagínate qué tranquilidad puede haber para un náufrago que fluctúa entre las olas. Y sin tranquilidad, ¿qué estudios? ¿Y qué alegría y entusiasmo, fuente de toda afición? ¡Oh siglos más que de hierro! ¡Oh magnánimo Ulises -si ya no fuiste una pura creación de Homero-, pues tú tenías a dónde dirigir tu carrera! Mis adversidades son mayores, por cuanto fuera del hado no tengo otro destino. Lo 
que me escribes de los turcos lo veo y me duele. Deseo el remedio y apenas tengo esperanza de ello. Que Cristo venga en nuestro socorro. No hay límite al dolor, si uno quiere entregarse a él.

El humanista valenciano conjuga los conceptos de destino y fortuna cuando dice que fuera del hado no tiene otro destino, o lo que es lo mismo, su destino es vivir al albur del penduleo de la fortuna. Nada en su vida reposa sobre la previsión. Se diría que la providencia quiso hacer de él un atleta bien curtido transformando su existencia en un sobrellevar el capricho de las situaciones. Fortuna y destino quedan identificados a consecuencia de la vorágine de las circunstancias. Pero Vives apunta en esta carta también dirigida a su amigo Cranevelt otros dos temas recurrentes: (1) su preocupación por cómo podrá dedicarse a escribir en medio de estas turbulencias y (2) la convicción de que sólo Cristo puede remediar su situación y socorrerle. En realidad concebía la escritura como un servicio y una vocación irrenunciable. A esto lo llama utilidad, que es algo que está más allá de la propia fama (Jiménez Delgado, 1978: 534):

Cierto que en otro tiempo me llenaba de admiración la fama, vista de lejos, y corría tras ella; ahora, puesta más a mis alcances y casi tocada con las manos, entiendo que es una sombra totalmente vana y más vanos aún los que tratan de captarla. Si en algo puedo ser útil a la conducta de los demás, esto es en definitiva lo que tengo por sólido y duradero. Te lo digo, para que no me saques a relucir tantas veces el espejismo de la fama, como estímulo; pues quiero que sepas que no le doy ninguna importancia y que no me siento estimulado por ella más que por una brisa muy tenue; me estimulas más sacándome a relucir el provecho de los demás, y por esto precisamente te considero a ti más feliz, más que por la fama de tu nombre, extendida por todo lo ancho y largo de la tierra, que a ti con justicia te cupo en suerte; pero si se unen estos tos extremos, merecer y alcanzar, ciertamente lo preferiré mucho más.

Escribe estas palabras a Erasmo, aunque realmente no sabríamos decir si el holandés estaría totalmente de acuerdo con el español en anteponer utilidad a fama. La razón de esta afirmación es que la fama es lábil y huidiza, y siempre resulta más provechoso dedicarse al aplauso de Cristo, que nunca decae porque se sustancia en la virtud, en vez de entregarse a la búsqueda del aplauso de los hombres. Así se lo dijo al propio Erasmo con la imagen tan querida para él de que la vida es una comedia (Jiménez Delgado 1978: 238):

Ha pasado para ti la mayor parte de la comedia de la vida; lo que resta dedícalo a ganar aplausos, no sólo de los espectadores y de tus coetáneos, sino de Cristo, a quien has consagrado tantos sudores y trabajos, de tu conciencia, y, si también apeteces aplausos de los que tienen sus miradas puestas en ti, que sea más bien de los venideros que de los espectadores presentes; pues ellos, los venideros, purificados de la animosidad y de las demás pasiones, contemplarán a un Erasmo auténtico en su inocencia y te tributarán las alabanzas que te mereces con tanta más prodigalidad, cuanto fueron más malignos contigo los hombres de tu siglo. Tu valor personal es menos conocido para aquellos con quienes has vivido, como vemos que aconteció también a Sócrates. (...) Y esto sí que será vivir al fin sin ansiedad ni congoja, y tu vida, aureolada con muchas canas, te hará despreciar los aullidos de muchos, y tú, como desatado y libre de los hados y colocado en un elevado puesto de honor para todos los hombres de bien, lo verás todo debajo de tus pies.

Vives aconseja esto al holandés consciente de que éste enfilaba el último tramo de su vida. En esas circunstancias lo importante a su juicio es dedicarse al cultivo del alma. Vives coloca entonces a Cristo junto a la conciencia, de la que tanto habla en el Diálogo de doctrina Christiana (Calero-Coronel: 2009), como opuesta a la virtù en Maquiavelo. En efecto, tiene a la conciencia como el auténtico fiel del comportamiento de los hombres. No es la fuerza, la estrategia, la sagacidad o capacidad de manipular 
las circunstancias lo que debe regir la vida humana; es la conciencia como criterio de elección, de decisión y de valoración. Pero hay algo más: la auténtica fama es la purificada del interés presente, es la fama histórica, que nace de lo que dicen aquellos que reciben las obras propias póstumamente. Ellos sólo valoran lo escrito según el provecho que reporta, despojado ya el autor de toda polémica o interés espurio. Por ello le dice a Erasmo que tenga bajo control el anhelo de buena reputación, ya que en todo caso el hombre tiene en su mano las decisiones sobre los libros, pero no el resultado final de las cosas. Esta es otro de los pensamientos que Vives comparte con Séneca (Jiménez Delgado, 1978: 309-10):

Que me perdone Cristo, si creo haber merecido una reputación mayor que la que a mi nombre corresponde. Y a fe que muchas veces me maravilla que la fama me favorezca tan desproporcionadamente. Por eso yo no llevo a mal lo que él dijo, pues en esto la cosa ha venido mejor de lo que razonablemente se podía desear. ¿Qué? ¿Si yo me hubiera persuadido a mí mismo que había llegado al ápice y pensara que los libros que yo escribo son los mejores y más doctos? Con todo no ignoro que es un favor singular del genio esa vida que se comunica a las obras literarias, y que es la fortuna la que otorga a cada cosa el valor y la inmortalidad que tienen, y que nosotros somos dueños de los proyectos, no del resultado. Por consiguiente, es propio del sabio preparar lo que está en su mano con la mayor maestría y diligencia posible y ponerse luego tranquilo en poder de la fortuna; ya que en la vida no hay que atribuir al hombre probo más que la culpa. Estos pensamientos me consolarían si fuera un desconocido para los eruditos y los sabios; pero como de hecho soy incluso más famoso de lo que muchas veces quisiera, para que muchos hombres no adviertan en mis obras su penuria, pues veo que es tan grande mi impericia, que por pudor me veo obligado a confesarla, para que lo que los demás no pueden menos de detectar, me anticipe yo a ponerlo por delante, aminorando así la culpa.

Pocos hombres del renacimiento tuvieron en menos la gloria que Vives. A su juicio no toda lucha está justificada, no toda estrategia es razonable y no todo objetivo es igualmente aceptable (Jiménez Delgado, 1978: 311s):

¡Qué miserable la gloria de los ingenios que no puede cimentarse sino en las sombras de la fantasía! Yo, por mi parte, renuncio ya desde ahora a la gloria y a todos los estudios, si hay que ir necesariamente por ese camino. Me avergüenza mi condición de escritor, si no ha de publicarse libreo alguno, que no cuente con la aprobación de la avaricia de los libreros, de suerte que estén las librerías llenas de Kempones, de Brechtones y de Torrentinos, y apenas se encuentre un sólo Cicerón. (...) ¡Váyase la gloria a la porra, si tan gran servidumbre comporta, que no se pueda decir una palabra con libertad; mientras que lo que no buscan la gloria, pueden decir lo que se les antoje! (...) Mi amor para con él no es tan pequeño, que quiera que salga de las prensas de Froben nada mío con daño suyo. No ha merecido él de mí tal cosa. Que no piense que yo me voy a enfadar con él, si no edita mis obras; haga lo que crea que más conviene a sus intereses. Pero ya son demasiadas las tonterías, máxime tratándose de ti.

Desde esta perspectiva adquiere su verdadera dimensión que Vives tenga por propósito medular de su vida el dedicarse a escribir. Pero este propósito sólo alcanza su justeza en el segundo pilar en el que Vives asienta su quehacer: en el compromiso cristiano. Éste es para él irrenunciable y será lo que le aparte de autores como Maquiavelo. En ello radica su concepto de providencia, una providencia cristológica en la que imagina a Jesús como único asidero, porque, ante la ceguera de las situaciones, es Cristo el único que puede ordenar la situación. Confiar en él es la única solución bien para resolver los conflictos, bien para sobrellevarlos con entereza. Confiar no significa intelectualizar, porque a Vives no interesa indagar los designios de la providencia como herencia también senequista y paulina-, sino saber aceptarlos y felicitarse por ellos. Por eso le escribirá a Cranevelt lo siguiente (Jiménez Delgado, 1978: 383): 
La fortuna con tantos golpes llegará al fin a golpear en vano, es decir, en un callo durísimo. Pero vea Cristo lo que me conviene. No hay motivo tan terrible de queja, que la naturaleza humana no llegue a soportar a fuerza de sufrir.

Este pensamiento de la fortuna golpeando en un callo puede partir del $D e$ providentia antes mencionado. La fortuna, a fuerza de ahormar al ser humano, consigue que las adversidades no le afecten. Vives cristianiza la idea y alude, como cabe esperarse a Cristo, que es el que sabe siempre lo que conviene. A ello se une el propio convencimiento de que la naturaleza humana está preparada para sufrir todo lo que le acontezca. Véase que Vives no plantea un ataque contra la fortuna, ni siquiera inquiere sobre la justicia y justeza de esos embates. La respuesta cristiana a la fortuna no es la virtù maquiavélica, sino abandonarse en Cristo, que es donde las cosas encuentran sentido -vea Cristo lo que me conviene.

Resulta obvio, en consecuencia, que el cristianismo que subyace en estas palabras no es intelectual, y por ello, el consuelo ante la fortuna que Vives promueve no es el socrático intelectualismo de Séneca basado en comprender la razón de ser del devenir de los acontecimientos. El consuelo en el valenciano nace de saber estar por encima de la fortuna gracias a la compañía de Cristo. El consuelo es saberse sostenido por el amor de Cristo. Por eso considera que los hados nunca presionan más allá de lo que la naturaleza puede soportar. Esa confianza es la que mantiene intacta su confianza como cristiano. Ese es el consuelo callado de Dios: callado porque no nace de la razón, sino de la fe (Jiménez Delgado, 1978: 391):

La Fortuna sigue, fiel a sí misma, ensañándose contra mi padre y contra todos los míos e incluso contra mí mismo; pues lo que a ellos hace, pienso que también me lo hace a mí, ya que amo a todos ellos no menos que a mí mismo. Pero el Autor soberano de este mundo, a cuyas leyes están sometidas todas nuestras cosas, así como conoce la razón y las causas de todos los acontecimientos, consuela igualmente calladamente con su consejo y nos manda preceptivamente que soportemos con tranquilidad de espíritu todas las contrariedades.

Estos pensamientos, como en el caso de Budé, eran compartidos por otros amigos, porque todos participaban de una idea de la religión interior y moral. Por eso Juan de Vergara le escribe el 12 de abril de 1527 para mostrarle su solidaridad ante el procesamiento de su padre, y lo hace dejando claro que no se apunta a la crítica fácil contra su familia, porque por encima de la desgracia padecida, Vives merece el aprecio que va más allá de las contingencias (Jiménez Delgado, 1978, 456):

El infortunio de tu padre lo llevé, como era deber mío, muy mal. Pero no pienses que por ese motivo ha decrecido lo más mínimo mi amor hacia ti. No soy de sentimientos tan bajos. Tú te has labrado para todos los buenos tan excelsa gloria, que no hay nada fuera de ti que pueda oscurecerla. Esta desgracia ha provenido de una circunstancia de todo ajena a tu persona (Dios quiso que a ti sólo te rozara) y tienes motivo para darle gracias. Pues no le ha parecido bastante hacerte ilustre y conspicuo con el prestigio de toda clase de virtudes, sino que te concedió también múltiples ocasiones para comunicar tu gloria a muchos otros. Conoces lo de fuera, según decían los estoicos. Que ni en los bienes ni en los males hay que pensar que uno ha perdido nada bueno, sino que más bien lo ha alcanzado, es a saber, la fortaleza, la ecuanimidad, la resistencia al dolor, virtudes todas ellas que debes juzgar que han sido y son para ayuda tuya y para la ayuda de todo aquel que tenga que soportar adversidades. Pero todo esto ¿cuánto mejor lo sabes tú que yo? 
En efecto, si, en un caso tan delicado, a Vives la acusación de judaísmo contra su padre sólo le rozó, esta circunstancia, a juicio de Vergara, fue por obra de la providencia. Recurre entonces Vergara al argumento ya mencionado de Séneca: a los buenos las malas circunstancias les acontece para ejercicio de su alma. Vives, gracias a esas circunstancias, ha atesorado fortaleza, ecuanimidad y resistencia. Ahí es donde se descubre la providencia, que se preocupa de lo verdaderamente importante, es decir, la virtud y la formación interior del hombre. Lo que queda más allá de eso -todo lo externo, en lo que se incluye incluso la vida- tiene un valor instrumental con respecto a lo anterior. Este pensamiento también profundamente cristiano se reitera una y otra vez en las obras de Vives y, en especial, en sus cartas, donde nuestro autor emerge con tintes más personales. En este contexto tanto el término de hado como el de fortuna se ven arrastrados por el de providencia. En esto consiste el humanismo cristiano erasmista-vivesiano, en el que se sostiene que todos los hombres forman una unidad -un cuerpo, por hablar con san Pablo- en el que cada uno tiene una misión que cumplir según el carisma que le corresponda. Vives expone este pensamiento con la metáfora ya citada de la comedia: la vida sería una comedia en la que cada hombre es identificado con un personaje. Todo esto lo explicó con claridad en su Escolta del alma (Riber 1992; I 1189):

87 Comoedia, vita humana (Comedia es la vida del hombre).

Y, efectivamente, la vida del hombre viene a ser una representación escénica, en la cual cada uno desempeña el personaje que se le señaló. Hay que procurar que en esa comedia anden las pasiones moderadas, porque no sea catastrófico ni manchado de sangre el desenlace, como suele ser en las tragedias, sino apacible y risueño, como acostumbra ser en las comedias. Y de ahí el otro aforismo.

88. Ne vita, tragoedia (No sea trágica la vida).

A saber: que la vida no degenere en tragedia, donde toda la acción es turbulenta y truculenta.

Para entender estas aseveraciones bastaría leer la Fabula de Homine, en cuyo prefacio escribió lo siguiente (Jiménez Delgado 1978: 131-2):

El primero de estos opúsculos es el de La Fabula del hombre, es decir, del teatro del mundo, en el cual cada uno tiene que desempeñar su papel, correspondiendo a los hombres la parte principal. El tema es ya viejo y contiene, en medio de bromas, muchas cosas serias. Efectivamente, por poco que remontemos nuestros pensamiento, puede ponérsenos de manifiesto la ruindad de esas cosas, que ansiosos y solícitos buscamos con gran ahínco, ciegos y locos, y en consecuencia impulsarnos a deseos más elevados. Porque, a decir verdad, todo lo que contiene la vida del hombre, fuera de la virtud, a manera de ciertos juegos infantiles, son cosa de risa y, como sueños vanos, se desvanecen al punto. Tengo el propósito, si algún día tuviere más tiempo, de desarrollar este mismo tema con la extensión que se merece. Ahora no he hecho más que delinear los trazos generales.

Los sueños vanos de la vida fueron ejemplificados por el propio Vives con la historieta que narró en carta al Duque de Béjar en la que contaba la experiencia del borracho de Brujas. La conclusión es clara: todo hombre tiene un cometido, una vocación vital que está relacionada con la búsqueda de las cosas verdaderamente importantes. Por ello, todo lo que no sea empeñarse en la virtud es un juego infantil. En este sentido, la vida se le plantea como un sueño con un plan preestablecido. La tarea del hombre es aprender a distinguir entre el sueño y la realidad para alcanzar la ansiada meta del conócete-a-ti-mismo. La referida carta al Duque de Béjar data aproximadamente del 1532 
(Jiménez Delgado 1978: 570-2). En ella cuenta una historieta acerca del sueño de la vida. Se relata cómo Felipe, duque de los belgas, tras una noche de fiesta y mientras paseaba por Brujas con unos amigos de francachela, encontró a un hombre borracho durmiendo en la calle y, entonces, Parecióle oportuno hacer con él la experiencia de cómo nuestra vida es una comedia, tema del que a menudo ellos habían hablado. Mandó que llevaran aquel hombre a palacio y que lo acostaran en la cama del duque. Al día siguiente aquel hombre del pueblo amaneció sobre la cama del duque y lo trataron todo el día como al duque hasta que, por la noche, le sirvieron una comida copiosa regada con buen vino hasta que volvió a quedar profundamente bebido y dormido. Entonces el hombre fue devuelto de nuevo a la calle con sus ropas del día anterior. Narra entonces el despertar de aquel borracho del siguiente modo (Jiménez Delgado 1978: 572):

Al día siguiente, al despertar, comenzó a pensar para sus adentros en aquella vida del duque, sin saber de cierto si había sido realidad o sueño, que se le había representado mientras dormía. Por fin, cotejando todos los indicios y las pruebas, sacó la conclusión de que había sido un sueño y como tal lo contó a su mujer, a sus hijos y a sus amigos.

¿Qué diferencia hay entre aquel día del borracho y algunos años de nuestra vida? Ninguna, en absoluto, sino que el nuestro es un sueño algo más largo. Ciertamente es lo mismo que si uno sueña solo una hora y otro sueña diez. No he oído hace tiempo nada más exacto y expresivo para explicar la caducidad de la vida.

Me pareció que debía escribirte este relato, porque me consta que te agradan estas fábulas, gracias a las cuales nuestro espíritu se halla mejor dispuesto para la virtud

En consecuencia, ante la caducidad de la vida, lo único importante es la virtud y aquellas cosas que disponen al hombre para la vida eterna. Esta vida resulta como un sueño, en el que lo único importante es lo superior. De este modo, como se ha dicho, se construye la teoría humanístico-cristiana del destino y de la fortuna como providencia, una providencia que, en manos de Cristo, enseña al hombre a valorar en su justa medida el auténtico peso de las cosas. Por todo ello el concepto de fortuna es inseparable del de virtud, tal y como ya se manifestaba el texto anterior de Séneca.

\section{VIRTUS CRISTIANA Y VIRTÙ MAQUIAVÉLICA.}

El planteamiento expuesto contrasta, como hemos venido afirmando, con la elaboración que Maquiavelo hace del par fortuna-virtù, convertido en clave de una teoría política contradictoria con la vivesiana. Ambos autores parten de la misma tradición clásica y medieval, pero Maquiavelo procede a redefinir las nociones de fortuna y de virtud -virtù-. Para el italiano, como es esperable, la fortuna puede ser adversa o favorable, mientras que la virtù sería la capacidad de hombre para moverse dentro de los devaneos de la fortuna y sacar provecho de ellos (Gramsci 1949; Heller 1980; Conde 2003). La virtud ya no es como en Vives un absoluto vital regido por los principios morales del cristianismo erasmista, sino que es una capacidad práctica para sacar el mayor provecho de la vida. El término deja de ser moral para transformarse en una noción de la praxis política. De hecho la virtù no sólo implica prudencia, saber hacer, fortaleza, sino sobre todo astucia y estrategia. En cierto modo en los espejos de príncipe está ya presente la idea de que los gobernantes deben tener astucia y 
estrategia, pero siempre subordinadas a los valores morales. Así sucede también en el renacimiento donde F. Petrarca, G. Pontano, B. Sacchi o F. Patrizi identificarán la virtud del gobernante con la honestidad o magnanimidad de las que hablaban los clásicos, pero eso sí, sancionada con la idea cristiana de justicia. En estos textos no hay divorcio entre el interés político y la moral. Este es el estadio de la discusión que encontramos en Vives, totalmente diferente del que puede verse en Maquiavelo.

Maquiavelo separa el término virtù de sus acepciones cristianas y lo utiliza en una significación que se acerca a la del mundo clásico. Véase cómo usa el término por el pasaje de la estrategia del arquero en el Principe VI 2s $(1966,59 \mathrm{~s})$ :

Perché, camminando gli uomini sempre per le vie battute da altri e procedendo nelle azioni loro con le imitazioni, né si potendo le vie d'altri al tutto tenere né alla virtú di quegli che tu imiti aggiugnere, debbe uno uomo prudente entrare sempre per vie battute da uomini grandi, e quegli che sono stati eccellentissimi imitare: acciò che, se la sua virtù non vi arriva, almeno ne renda qualche odore; $\mathrm{e}$ fare como gli arcieri prudenti, a' quali parendo el luogo dove desegnano ferire troppo lontano, e conoscendo fino a quanto va la virtù del loro arco, pongono la mira assai piú alta che il luogo destinato, non per aggiugnere con la loro freccia a tanta altezza, ma per potere con lo aiuto di sí alta mira pervenire al disegno loro.

La virtud es, por tanto, perspicacia en la vida práctica. No es el fundamento moral de la existencia, sino la habilidad para manejar las causas finales. En este sentido, la virtud no deja de ser la herramienta para que el hombre someta a su yugo la fortuna. De hecho el italiano presenta al hombre como faber fortunae (Garin 1993:6), es decir como el hacedor de una fortuna que tiene por finalidad conseguir honor, gloria y fama (Skinner 1981: 39s). En el gobernante estos conceptos se materializan en la libertad dentro de las fronteras y en el imperium fuera de ellas (Hörnqvist 2004: 38). Juega Maquiavelo con la imagen de la virtud como elemento masculino de la vida y la fortuna como elemento femenino. Así considera que el cristianismo ha afeminado el mundo, porque prepara al hombre no para la actuación sino para soportar y sobrellevar el sufrimiento. Con esto ha debilitado las fuerzas del mundo y ha sobrevalorado la pujanza de fortuna. Todo esto sería atribuible a un sujeto como Vives, según ya se ha visto. Frente a todo eso escribe Maquiavelo en sus Discorsi II,2 (2000: 141s):

E se la religione nostra richiede che tu abbi in te fortezza, vuole che tu sia atto a patire più che a fare una cosa forte. Questo modo di vivere, adunque, pare che abbi renduto il mondo debole e datolo in preda agli uomini scelerati; i quali sicuramente lo possono maneggiare, veggendo come l'università degli uomini per andarne in Paradiso pensa più a sopportare le sue battiture che a vendicarle. E benché paia che si sia effeminato il mondo e disarmato il Cielo, nasce più, senza dubbio, dalla viltà degli uomini che hanno interpretato la nostra religione secondo l'ozio e non secondo la virtù.

En síntesis, la virtud en Maquiavelo es una herramienta política y vital y no un valor moral. Es una téchne que parte de la voluntad, de la destreza y de la estrategia. La virtud no es docilidad a la providencia, sino actuación práctica en la vida (Conde 1976; Chabod 1984; Russo 1988; Dotti 2003). Esto es sin duda una gran innovación, a saber, hacer que la virtud radique en cierto modo en las propias leyes, que son la herramienta con las que el hombre, frente a las bestias construye la realidad. Con todo, el príncipe debe saber manejar no sólo la ley, sino también la fuerza. Lo dijo claramente en Il Principe XVIII, 2-6 (1966: 107): 
Dovette adunque sapere como e' sono dua generazioni di combattere: l'uno, con le leggi; l'altro, con la forza. Quel primo è proprio dello uomo; quel secondo, delle bestie. Ma perché el primo molte volte non basta, conviene ricorrere al secondo: pertanto a uno principe è necessario sapere bene usare la bestia $\mathrm{e}$ lo uomo. Questa parte è suta insegnata alli principi copertamente da li antichi scrittori, é quali scrivono come Achille e molti altri di quelli principi antichi furno dati a nutrire a Chirone centauro, che sotto la sua disciplina li custodissi. Il che non vueole dire altro, avere per precettore uno mezzo bestia e mezzo uomo, se non che bisogna a uno principe sapere usare l'una e l'altra natura: e l'una sanza l'altra non è durabile.

En definitiva, frente a un Vives que no concibe una vida sin prosperidad y sin adversidad, porque estas dos circunstancias son los cinceles que labran el corazón humano y lo conducen a la virtud, Maquiavelo elabora un concepto novedoso de virtud como cincel para determinar en la praxis el destino humano. Maquiavelo ha secularizado el término. Estas dos visiones son las que se enfrentan en una obra como el Lazarillo de Tormes. El profesor F. Calero (2006) ha demostrado que el autor de esta genial obra fue precisamente J.L. Vives. No se olvide que el título de la obra es La vida de Lazarillo de Tormes, y de sus fortunas y adversidades. Y en él, con la hendíadis fortunas y adversidades, se alude a las desdichas que provoca la fortuna en la vida de Lázaro. El tema de la obra es la virtù de Lázaro, es decir, el conjunto de su aprendizaje y luego de su estrategia para domeñar la fortuna y, con ello, sus adversidades.

Recuérdese a este respecto la conversación con la reina Catalina antes mencionada y también aquella expresión que Budé compartía según la cual había que librarse del montón de afortunados. Dicho todo esto, el autor del Lazarillo parece poner en escena a un personaje que con el concurso de la virtù práctica va a conseguir cambiar su fortuna. El final de la obra con el casamiento de Lázaro con una amancebada lo que demuestra es que ese ideal de virtù sólo desemboca en situaciones inmorales. Por tanto, Lázaro, que parece ser el modelo del éxito de la virtù, se convierte en el contrajemplo para un humanista que considera que virtud, desde el cristianismo, no es luchar a toda costa por conseguir lo material, sino que la virtud está más cercana a un crecimiento interior y a una confianza ciega en la providencia. En Vives la virtud es inseparable de la sabiduría, la prudencia y la piedad (Fernández Santamaría 1990: 227-36). En el Lazarillo se contraponen dos concepciones antropológicas: la que prefigura al hombre como un ser busca el interés propio en lo material, y la del hombre que orienta su vida con criterios trascendentales. Por eso en el prólogo se habla de soldados que ponen en peligro la vida por la fama o incluso un sacerdote que lo que anhela es la fama de ser un buen predicador $\left(2006^{19}: 6-7\right)$ :

¿Quién piensa que el soldado que es primero del escala tiene más aborrescido el vivir? No, por cierto; mas el deseo de alabanza le hace ponerse en peligro; $y$, así, en las artes y letras es lo mesmo. Predica muy bien el presentado y es hombre que desea mucho el provecho de las ánimas; mas pregunten a su merced si le pesa cuando le dicen: ¡Oh qué maravillosamente lo ha hecho Vuestra Reverencia!

La virtù, en consecuencia, sitúa al hombre en el terreno de lo material, de aquellos bienes perecederos ante los que Vives parece mostrar indiferencia. Por eso se alude al soldado y a los que se dedican a las artes y letras, es decir, a todos los estamentos sociales. Incluso al que se dedica del cuidado de las almas con una idea de virtud cristiana. A ese lo que le mueve es la fama que obtienen sus predicaciones. 
Por eso habla del presentado, es decir, del teólogo que espera el título de maestro. Lo que le motiva a egresar no es el ministerio sacerdotal, sino la fama que éste le pueda reportar. En una sociedad en la que todos buscan lo fungible tratando de contener las desgracias de la fortuna, Lázaro puede proponerse como ejemplo, ya que es el hombre por excelencia que vive con tantas fortunas, peligros y adversidades (2006 ${ }^{19}$ : 9) pero que, a lo largo de la obra, logrará sobreponerse a esa losa que obturaba su vida. Lázaro sale a flote con fuerza y maña, es decir, con estrategia frente a esas adversidades (2006 ${ }^{19}$ : 10s):

Y pues Vuestra Merced escribe se le escriba y relate el caso muy por extenso, parescióme no tomalle por el medio, sino del principio, porque se tenga entera noticia de mi persona; y también porque consideren los que heredaron nobles estados cuán poco se les debe, pues Fortuna fue con ellos parcial, y cuánto más hicieron los que, siéndoles contraria, con fuerza y maña remando, salieron a buen puerto.

El problema está en plantear si el puerto al que Lázaro llega es realmente un destino aceptable desde el punto de vista cristiano. A juicio del protagonista su destino es modélico porque proviene no de la herencia o del apego de la fortuna, sino que surge del esfuerzo, de la estrategia y de la virtù. Sin embargo, Lázaro vive dentro de un imaginario cristiano, y por ello procede a caricaturizado. De este modo se presenta una situación social en el que los personajes aquietan su conciencia alternativamente con el uso de la virtù y con la recurrencia a tópicos cristianos. Esta incoherencia de clamar por lo que no se cree, ya que se vive desde un presupuesto en el que la providencia es pasada por alto, destaca, por ejemplo, en el tratado II con el episodio del calderero, que Lázaro considera obra de la providencia $\left(2006^{19}\right.$ : $\left.54 \mathrm{~s}\right)$ :

Pues estando en tal aflición, cual plega al Señor librar della a todo fiel cristiano, y sin saber darme consejo, viéndome ir de mal en peor, un día que el cuitado, ruin y lacerado de mi amo había ido fuera del lugar, llegóse acaso a mi puerta un calderero, el cual yo creo que fue ángel enviado a mi por la mano de Dios en aquel hábito.

¿En qué queda la providencia? En un recurso popular probablemente irónico para explicar lo que no se ha previsto. En consecuencia, si la fortuna ya ha quedado controlada por la virtù, aquella parcela que siempre queda al margen de lo controlable -acaso-, será llamada providencia. Una providencia en apariencia cristiana pero en realidad secularizada. Está secularizada porque Lázaro habla de la providencia como el socorro que Cristo provee a los que están afligidos y son fieles cristianos. Sin embargo, ni él es buen cristiano ni su aflicción es comparable a la de aquellos a los que Cristo denominó bienaventurados. Lazaro recurre a la misma explicación de religiosidad externa y a este concepto vulgar de providencia en muchos momentos en los que parece que su estrategia no surte efecto. Recuérdese también el episodio con el clérigo de Maqueda, cuando éste reforzó su arcón con clavos y tablas. Entonces Lázaro, al ver que su virtù ha encontrado un obstáculo insalvable, exclama (2006 ${ }^{19}$ : 60s):

¡Oh Señor mío -dije yo entonces- a cuánta miseria y fortuna y desastres estamos puestos los nascidos y cuán poco turan los placeres de esta nuestra trabajosa vida! Heme aquí que pensaba con este pobre y triste remedio remediar y pasar mi lacería y estaba ya cuanto que alegre y de buena ventura. Mas no quiso mi desdicha, despertando a este lacerado de mi amo y poniéndole más diligencia de la que él de suyo se tenía (pues los míseros, por la mayor parte, nunca de aquélla carecen), agora, cerrando los agujeros del arca, cierrase la puerta de mi consuelo y abriese a mis trabajos. 
Lázaro valora su vida según los placeres, es decir, según el rédito de su virtù manifestada en la expresión trabajosa vida, porque esta expresión a lo que se refiere son a los esfuerzos y penalidades que se pasan en la vida cuando el hombre lucha por escapar de la adversidad. En este sentido, cuando el clérigo descubre que Lázaro tenía una copia de la llave del arcón -otro acontecimiento que Lázaro no preveía- lo atribuye al hado o por mejor decir, a mis pecados $\left(2006^{19}: 68\right)$, de forma que los acontecimientos inesperados de los que saca provecho son vinculados con la providencia y aquellos de los que no saca ventaja lo son con el hado. En este último caso también recurre al imaginario popular con el concepto de pecado, ya que se explica el obstáculo a su virtù como consecuencia de una insuficiencia moral. Pero sucede lo mismo que con el concepto de providencia, la moralidad y el pecado son dos términos usados simplemente como fórmulas hechas, porque en ningún momento Lázaro habla de arrepentimiento ni de cambio de estrategia.

Nos encontramos, por tanto, ante uso de palabras en un sentido tópico que contrasta con una actuación que nada tiene que ver con la ideología de fondo de las palabras. En este sentido cuando el mundo parece juzgar según unas apariencias que nada tiene que ver de cristianas. Dios es en esta circunstancia el que conoce el corazón de las personas, pero ese conocimiento no afecta al valor social de las gentes. Lo dice claramente en el episodio del escudero (2006 $\left.{ }^{19}: 83 \mathrm{~s}\right)$ :

¡Bendito seáis Vós, Señor -quedé yo diciendo-, que dais la enfermedad y ponéis el remedio! ¿Quién encontrará a aquel mi señor que no piense, según él contento de sí lleva, haber anoche bien cenado y dormido en buena cama, y, aún agora es de mañana, no le cuenten por muy bien almorzado? ¡Grandes secretos, son Señor, los que Vós hacéis y las gentes ignoran i ¿A quién no engañarán aquella buena disposición y razonable capa y sayo? ¿Y quién pensará que aquel gentil hombre se pasó todo el día sin comer, con aquel mendrugo de pan que su criado Lázaro trujo un día y una noche en el arca de su seno, do no se le podía pegar mucha limpieza, y hoy, lavándose las manos y cara, a falta de paño de manos se hacía servir de la halda del sayo? Nadie, por cierto, lo sospechará. ¡Oh Señor, y cuántos de aquestos debéis Vós tener por el mundo derramados, que padescen por la negra que llaman honra lo que Vós no sufrirán!

De hecho, el escudero es un fracasado, pero lo es por su empeño en mantener la honra y aceptar su destino y no lugar por cambiarlo, dado que su estado no le permite más fingir una vida ociosa. Lázaro, sin embargo, lucha contra la fortuna y lo hará demostrando que la honra no sirve, como se pondrá de relieve al final de la novela. La negra honra del escudero él la tiene en nada y acepta su situación aunque haya quienes pongan en tela de juicio su honra. Así se lo aclara el clérigo del Salvador (2006 ${ }^{19}$ : 132s):

Lázaro de Tormes, quien ha de mirar a dichos de malas lenguas nunca medrará; digo esto porque no me maravillaría alguno, viendo entrar en mi casa a tu mujer y salir della. Ella entra muy a tu honra y suya. Y esto te lo prometo. Por tanto, no mires a lo que pueden decir, sino a lo que te toca: digo a tu provecho.

Esta idea de la negra honra aparece explicada por Vives en su obra Escolta del alma en la que identifica la honra o el honor con las cargas (Riber 1992; I 1191):

108 Honores, onera (cargas son los honores). Muchos cuidados y ansiedades tienen que soportar y puchos trabajos que afrontar las personas constituidas en dignidad y honor, máxime cuando se empeñan en conservarlos. No será el dicho menos elegante así: Fasces, Fasces. Eras las fasces (haces) las insignias de los magistrados romanos, y fasces (haces) son también las sarcias y fardajes. 
En consecuencia, el provecho es el concepto que resume la antropología de vida de Lázaro. Dios es, por tanto, un recurso lingüístico. La religión, como en Maquiavelo no es más que un obstáculo y, por tanto, queda apartada del juego de luchas que exige la virtù. Recuérdese al buldero tomando el nombre de Dios en vano, pero consiguiendo sus propósitos $\left(2006^{19}:\right.$ 119). En definitiva, la sociedad del Lazarillo se caracteriza por convivir en ella, por un lado, aquellos que no se han acomodado a la nueva situación -el escudero- y que están anclados en unas condiciones de vida penosas porque su clase social no le permite trabajar. Por otro lado, están los personajes como Lázaro, que lucha contra toda adversidad arrimándose a la clerecía, tras aprender que no su provecho no reside en un mendrugo de pan robado, sino en un consorcio en el que Dios es una excusa, un imaginario, una retórica. La virtud cristiana es otra retórica en ese mundo y esto es lo que el autor de la obra parece querer indicar. La virtù conduce a situaciones inmorales y lleva a un éxito centrado exclusivamente en lo material.

El Lazarillo se construye así como un contraejemplo en el que se escenifica los resultados inmorales de vivir apartado de la virtud cristiana. Entre esos resultados se encuentra el querer enfrentarse con la fortuna, dado que en un cristiano lo que se espera es vivir por encima de la fortuna confiado en la providencia. En consecuencia, Lázaro es el producto de una sociedad que lucha contra la fortuna para atesorar lo perecedero. El ejemplo contrario a Lázaro es el de Pompeyo tal y como lo perfila Vives en su Pompeius fugiens. En esta obra Vives propugna el menosprecio de la fortuna, ya que luchar para conseguir fortuna es combatir por lo que no depende del hombre porque no está en sus manos. Lázaro cree que luchando contra la fortuna llega a buen puerto, pero en realidad llega a una situación inestable basada en un engranaje de circunstancias que puede fallar en cualquier momento. No es esa la actitud cristiana que Vives exige tal y como lo dice en la dedicatoria de su Pompeius (Riber 1992: I 581):

porque hartas veces y copiosamente acostumbras, departiendo conmigo, tratar de cosas que atañen al menosprecio del mundo y al odio de la fortuna, y autorizas tu doctrina con los ejemplos de los varones antiguos y los preceptos de la religión cristiana.

Esta es la clave de la sociedad para un cristiano: el amor de Dios frente a las cosas del mundo. Esta es la bipolaridad que preside el Pompeius fugiens, y de ahí que afirme que es una obra que agradará a los mal afortunados (Riber 1992: I, 581s):

Y aun aquellos que fuesen mimados de la próspera Fortuna, van a tomar no poco solaz cuando verán pintadas como en una tabla las más bruscas alternativas de la suerte y aprenderán a no creer en ninguna Fortuna, aun cuando se les muestre risueña y blanda. Muy discretamente lo dice el Cómico: Cuando halaga, ronda y espía. En esa lectura se prepararán para la vida, pues como sea que las leyes por que se rigen las cosas humanas son gobernadas a su vez por la veleidad y la inconstancia, soportarán no ya con ánimo igual, sino que también grande y excelso, todo cuanto les acaeciere; y no solamente la Fortuna hosca y cruel, sino también la halagüeña y lisonjera, que hartas veces es más difícil de llevar bien que la brava y sañuda

Como ya se ha dicho, combatir con la fortuna es luchar por conseguir lo que es incontrolable por naturaleza, es decir, luchar por adquirir fama, riqueza, prestigio etc. Pompeyo parece consciente de ello y medita del siguiente modo (Riber 1992: I 593):

Yo no veo qué cosa pueda reprender en mí ninguno. Hice todo cuanto a un mortal le es hacedero. Servido me he de la benignidad de la Fortuna en lo que al bien de mi patria convenía, en cuanto a la modestia 
y a todas las otras virtudes pertenecía, y en lo que, para ayuda y socorro de los buenos, era mejor. Jamás hubo en mí señal alguna de insolencia. Mi buena ventura fue que me pude afanar siempre para que Roma de mis amores, en reposo inalterado, en paz olímpica, fuese señora del mundo. Porque no cayesen en la servidumbre de César hice la guerra civil, y en esa ocasión la Fortuna volvióse contra mí, en una de sus veleidades acostumbradas. ¿Qué debo hacer? Por ventura, ¿puedo yo dar a mis cosas un resultado feliz aun cuando haya puesto en esa empresa mi corazón y mis fuerzas tantas cuantas tuve? Esto me tiene maravillado y atónito y no creo haber sido hecho sin gran razón, por más que yo no la alcance.

Lo tornadizo es siempre malo, así que Pompeyo aprovecha la buena fortuna para el bien de Roma y no para su lucro personal y, cuando la fortuna gira y se le torna enemiga, acepta con valentía el devenir de los acontecimientos. Éste es el modelo que Vives tiene para contraponerlo a la fortuna y a la virtù de un Maquiavelo. $Y$, si en el Lazarillo muestra la inutilidad de luchar por un buen puerto que se cifra en vivir bajo el amparo de un clérigo amancebado, en el Pompeius muestra cómo la virtud es anteponer el bien colectivo al personal y aceptar lo inesperado con dignidad. Pompeyo representa la dignidad del éxito y la dignidad del fracaso, mientras que Lázaro encarna la falta de dignidad en el éxito. Este pensamiento condiciona una teoría política basada en el deber y en la justicia cristiana más que en la estrategia y la astucia. No puede ser de otro modo porque la fortuna no se la puede atenazar, sino que hay que vivir por encima de ella, ya que lo que hoy da mañana lo quita (Vives 1997: 167):

El cartaginés Hasdrúbal fue capturado y sacado de su propio campamento por el ardor de los siracusanos, a quienes, por cierto, tenía asediados. Los ingleses se apoderaron de Juan, rey de Francia, quien, teniendo numerosísimas tropas, había despreciado las escasas de los enemigos hasta el punto de haber rehusado su rendición bajo determinadas condiciones. La historia está llena de tales ejemplos; y, para no traer sólo ejemplos antiguos, ni a Francisco lo protegió su numeroso ejército, ni al papa Clemente toda la mismísima Roma ni el sagrado título de su dignidad, para que nadie crea que en la guerra tiene fuerzas tan grandes que no tenga que temer la mudanza de la fortuna; por esta razón, en efecto llamaron a Marte Mavorte, por así decir, el que hace cambiar las grandes empresas.

En lo mudable de la fortuna se basa la praxis política de Vives. El valenciano busca, por así decir, un asidero parmenídeo y un criterio firme y justo para delimitar lo que debe ser la actuación política. Ese elemento de estabilidad no puede residir en la fortuna, sino en la virtud cristiana. Por eso, cuando se inmiscuye en cuestiones políticas, siempre tiene por primer objetivo anteponer la justicia y la magnanimidad a la celebración del éxito o al lamento por el fracaso. Así lo hace un hombre que vivía obsesionado por contribuir a instaurar en Europa la concordia. En el Diálogo de los turcos aparece claro que el amor como trasunto de la paz es lo que define al cristiano (Vives 1992: 52):

Minos: ¿Qué hacen los príncipes? ¿qué los cristianos? ¿qué los turcos?

Poligragmon: Más o menos esas mismas cosas, y por doquier la guerra, las discordias, los odios.

Minos: Seguro que no entre los cristianos, pues a éstos nada recomendó más ni con más claridad aquel celestial maestro de sabiduría que el amor mutuo, y quiso que los suyos se distinguiesen por ese atributo.

Polipragmon: Pero en ninguna época, en ningún lugar hubo odios tan grandes como los de ahora entre ellos (...).

Por ello se atreve a escribir a Adriano VI al enterarse que su antiguo amigo había sido elegido papa. El valenciano sabe que es una osadía y así se lo comenta a 


\section{J. Aleandro en una carta de 1522 rogándole que también él escriba al nuevo pontífice} (Jiménez Delgado, 1978: 285-6):

Respecto a mis cosas no hay nada digno de mención. Todas ellas son, como de costumbre, poco seguras, por eso de que en mis resoluciones sigo generalmente las circunstancias, que si son alguna vez diferentes, ahora principalmente son inciertas y movedizas. Si los príncipes se unen en la paz, fácilmente tomaré alguna determinación. ¡Cuánto desearía que fuera esta la gloria de nuestro Pontífice: el ofrecer al mundo la paz que le está reclamando y como exigiendo dada su pasada conducta y su esperada bondad! Y esto estimo que será propio no sólo de su virtud y prudencia, sino de su felicidad, toda vez que por ambas partes, se han encendido los ánimos y exacerbado los odios, con muchas ofensas y daños de una y otra parte. Pero hay que probar la fortuna y con habilidad, o ayudarla o rechazarla, y no valerse de aquella palabra impotente de los filósofos en las determinaciones de los negocios. Por este motivo -jfíjate cuál ha sido mi audacia o mejor dicho mi temeridad!- no he dudado en escribir al propio Pontífice Máximo, fundado en nuestra vieja amistad, como si no hubiera distinción alguna entre el Romano Pontífice y el Obispo de Tortosa. Por lo demás, no ayuda sólo a los valientes, sino también a los atrevidos. Me gustaría que tú secundaras esta audacia mía. Ya sabes que hablamos aquí del médico Vives.

Obsérvese que Vives no está utilizando la fuerza ni artimañas en las que se pueden incluir la violencia o la mentira, sino sólo la persuasión de la palabra y las convicciones. Esta es la única arma legítima para un humanista cristiano. La paz se consigue con la persuasión y el debate y no con fuerza y maña. Esta idea va unida a la concepción del cristianismo como un instrumento de concordia y paz. Si el papa propicia la paz no estará haciendo otra cosa más que reconciliar a todos con Cristo. Esta idea de la paz, le dice también a Erasmo, se relaciona con que el papa sepa cuál es su lugar en la cristiandad, que precisamente no es el poder temporal. Por eso cifra su esperanza en que el papa tenga presente que es el príncipe de la paz y sobre todo autoridad religiosa y nada más. Vives lo deja todo en manos de un hado que bien puede identificarse con la providencia (Jiménez Delgado 1978: 268):

Hay grandes esperanzas puestas en el nuevo Papa; hasta el presente no ha dado muestras de energía. Piensa que se enardecerá con la entrevista que ha mantenido con el César el 16 de julio a la orilla del Cantábrico. Temo no se acuerde tanto de que es el Romano Pontífice, cuanto de su vieja sumisión al emperador, de suerte que abdique del peso de su autoridad ante el parecer de aquél. Mas si él mantiene la conciencia de quién es y no de quién ha sido, hay grandes esperanzas de paz. Pero dejemos esto a los hados.

Entregarse en manos de Cristo es la clave de todo progreso personal o colectivo. La misma visión tiene con respecto a los reyes. El 12 de marzo de 1525 le escribe a Enrique VIII para recordarle que debe estar a la altura de las circunstancias y debe ser magnánimo con el rey de Francia. En este sentido habla de controlar la fortuna en no dejarse arrastrar por el éxito y pierda de vista la perspectiva. Haber ganado una contienda le obliga a saber ponderar todas las circunstancias y no dejarse llevar por la vorágine de la victoria (Jiménez Delgado, 1978, 396-400):

Ahora espero que os esforzaréis y pondréis empeño en que entiendan todos, no sólo los presentes, sino también los venideros, a quienes llegare la fama de un hecho tan glorioso, que no sólo tuviste a él en vuestro poder, sino fuiste dueño de vos mismo; y que no os dejaste arrastrar por la fuerza imperiosa de la fortuna temeraria, sino que vos mismo la dominaste y que estos acontecimientos tan prósperos no te han hecho más insolente y arrogante, sino que te han hecho recordar la inestabilidad de las cosas prósperas y la versatilidad de los humanos infortunios, y que en vuestros adentros pensaréis que lo que sucedió al rey de Francia podía haber sucedido a cualquiera de vosotros, lo que Dios no permita, porque todo es común a todos y nadie está exento de la suerte de los hombres. Por eso abrigamos la dulce espe- 
ranza de que usaréis con templanza de vuestra victoria y de que no os ensañaréis en un pueblo inocente y falto de toda ayuda, ni devastaréis el más floreciente reino del mundo cristiano y de que no arrancaréis lo que podemos llamar el ojo segundo de toda Europa. Porque ¿qué culpa ha tenido el pueblo de que el rey se decidiera a declarar la guerra aun contra la voluntad, según dicen, de todos sus consejeros?

Ciertamente por lo que toca a vuestro provecho y al de vuestros pueblos, yo no doy tanta importancia al hecho de haber hecho prisionero al rey, cosa que hará que la guerra se acabe al momento o por lo menos sea más fácil y rápida, cuanto al ejemplo y enseñanza que ha de ser para vosotros, según la penetración del talento de cada uno y según su experiencia y prudencia. La primera enseñanza será no fiarse de ningún feliz resultado; la segunda, que no emprendáis la guerra a la ligera, sino que penséis antes los varios azares de la misma y qué inseguro es Marte, cómo muchas veces los vencidos, los puestos en fuga, los sitiados, los acorralados han vencido a los mismos vencedores de antes y han hecho prisioneros a los que les cercaban. Por último, cuánto daña a todo el reino, a tantas gentes y pueblos la ciega ambición y la audacia sin consejo de un hombre de bien.(...)

Al mismo tiempo pienso que no ignoráis qué importancia tiene esto para lograr vuestros deseos. Con aquella vuestra moderación y mansedumbre amansaréis todos los pueblos de Francia, apartaréis de ellos toda idea de venganza y arrancaréis de sus manos, por así decirlo, las armas en su propia defensa; pues hartas veces la desesperación ante los acontecimientos de la vida empuja a grandes y horribles crímenes, arrastrando por igual el ánimo de los hombres grandes y de los depravados. Además, porque robusteceríais vuestro poder, si buscarais por medio de la benevolencia grande y obsequiosa de vuestros propios súbditos aquella clemencia y dominio personal, que son la defensa más poderosa de un príncipe; y no habría nación ninguna que no os aceptara por rey, como regalo llovido del cielo, pues ¿qué hay más propio de la naturaleza de la divinidad que hacer el bien, ayudar, favorecer y conservar el mayor número de hombres?

Y por encima de todo esto, daríais satisfacción a Cristo, cuyo respeto y consideración debe estar frecuentemente ante vuestros ojos, porque en breve tendrás que comparecer ante su tribunal (porque ¿qué hay largo en la vida humana?), sin que te acompañe el ruido de la fortuna, sin distinguirte en nada de cualquier persona privada, y en ese momento sólo podrá aprovecharte tu vida, si la has vivido piadosa e inocentemente.

Estas palabras definen el proyecto político de Vives. A su juicio el éxito no debe ser una ocasión para perder de vista que hay valores superiores. El éxito que se emborracha en su propia buena fortuna da origen a desmanes y lleva a ignorar que un éxito no garantiza que siempre se vaya a disfrutar de buena fortuna. Por ello Vives aconseja a Enrique VIII manejar su victoria sobre Francia con ecuanimidad, respetando a los franceses y actuando como un auténtico cristiano. A su juicio, el gobernante cristiano cabal vive por encima de la fortuna, porque no se deja arrastrar por el éxito. En consecuencia, la vida es un terreno inestable en el que estamos a merced del curso de los acontecimientos. Vivir es encontrar un punto de apoyo para responder con ecuanimidad a la dicha y a la desdicha. Nada hay en estas consideraciones de la virtù maquiavélica, nada del hombre enfrentado a la virtud con la ley y la fuerza. El valenciano no enseña a aprovechar la oportunidad, sino que previene contra el que no sabe administrar las oportunidades y pierde la razón al obviar que sobre su triunfo están el bien general, la justicia y la moderación. En el fondo Vives considera que esas victorias son propiciadas por el propio Cristo para lograr con ella el bien común y no la vanagloria personal ${ }^{5}$.

\footnotetext{
${ }^{5}$ Pro 21,31: Se prepara al caballo para el combate la victoria la concede el Señor.

Sal 33, 16-9: No vence el rey por su gran ejército, no escapa el soldado por su mucha fuerza;
} 


\section{FORTUNA Y PROVIDENCIA.}

Vives en las múltiples ocasiones en que habla de la fortuna parece tener en mente la carta de Séneca en la que le advierte a Lucilio de que ducunt uolentem fata, nolentem trahunt -el destino conduce al que se le somete, al que se resiste lo arrastra$(107,11,5)$. En este sentido la fortuna se perfila como una fuerza irrefrenable sin que exista frente a ella ninguna virtù para contenerla. Léase lo que le escribe a Cranevelt el 17 de marzo de 1523 (Jiménez Delgado 1978: 300s):

Nosotros en cambio languideciendo a las veces de modorra, como en una borrasca nacida de una tempestad estival, que nos coge desprevenidos y de improviso, comenzamos a vomitar, a sentir náuseas, a asirnos a cualquier coas, a movernos de aquí para allá, a quejarnos mucho, a sentirnos muy afligidos, y por el mismo estado de las cosas, que creíamos muy seguro, ante la presencia del mal que no esperábamos, no sólo nos vemos agitados, sino hundidos; y cuanto nosotros, a quienes tú bromeando llamas estoicos, con más ahínco nos defendemos y resistimos a fuerza de valor, con tanto mayor ímpetu maneja la Fortuna nuestras pobres fuerzas o las máquinas de guerra contra nuestra fortaleza, para darnos a entender que no podemos defendernos ni con el escudo de nuestra virtud, sino que ella domina todas nuestras acciones, de las que se ha enseñoreado. Quien a ella se resiste, al fin tiene que hacer lo que ella mande. ¡Ojalá tuviera yo aquel vigor de alma, de que tú hablas, sea de broma sea en serio.

Me consuela ciertamente que el maestro de nuestra filosofía, que no es Zenón, sino Cristo, sitúe el desprecio de la Fortuna por encima de toda prosperidad y bienandanza; aunque por lo que a mí respecta la cantidad enorme de males privados nada significa cuando uno contempla las calamidades públicas. Porque ¿quién hay tan egoísta y complaciente consigo que se acuerde de sus males en medio de las perturbaciones públicas?

El valenciano habla con toda claridad: el consuelo ante una fortuna que conduce o arrastra no es el estoicismo, sino el cristianismo, en el que la fortuna queda relegada porque el cristiano no le planta cara, sino que la desprecia. En ese desprecio se incluye una relativización de lo dichoso y de lo desgraciado. Es aquí donde emerge la concepción cristiana de la providencia, vinculada a un concepto paulino de virtud. Desde esta perspectiva el Lazarillo es o la expresión de un esfuerzo baldío, porque el resultado final no hace mejor al protagonista, o la plasmación de un engaño: el de aquellos que se olvidan de Dios para confiar en sí mismos. La virtud cristiana es un escudo frente a la fortuna, pero no porque sea una estrategia de lucha, sino una actitud de asunción de la realidad. Reiterémoslo: Cristo no enseña a luchar contra la fortuna, sino a estar por encima de ella. En este sentido la existencia no es una lucha por nadar entre la adversidad y la prosperidad, sino un emerger por encima de esos hechos que son contingencias. Vinculado con esto está la crítica al individualismo de Lázaro y de todos aquellos que se rigen por la virtù porque, frente a estas tendencias está la preocupación por el progreso moral de toda la sociedad. La virtud cristiana se enlaza así con lo social frente al individualismo maquiavélico, y de ahí que se anteponga el bien común a la fortuna personal. Resultan por ello muy ilustrativas las palabras que escribe a Cranevelt el 22 de febrero de 1523 (Jiménez Delgado 1978: 296):

nada valen sus caballos para la victoria,

ni por su gran ejército se salvan.

Los ojos del Señor están puestos en quien lo teme,

en los que esperan su misericordia,

para librar sus vidas de la muerte

$y$ reanimarlos en tiempo de hambre. 
¡Felices los que viven tranquilos! Yo estoy también decidido a vivir en paz. Querría reconciliarme con la Fortuna a cualquier precio, mientras no sea a la fuerza; aunque veo que sin alguna de las dos o con las dos juntas (tales son las costumbres y el tiempo), es imposible lograr aquella famosa risa de Demócrito. ¡Oh grande reino de la Fortuna entre nosotros (me avergüenza decirlo), entre nosotros que profesamos la fe cristiana, cuando Cristo nada procuró más que vernos alejados lo más posible de negociar con ella! Pero protesta y serás llamado hereje. Mejor será precaver que quejarse.

Esta carta es toda una declaración de intenciones que explica el contraejemplo de Lázaro de Tormes. En efecto, asevera que no querría reconciliarse -sobreponerse-con la fortuna a través la fuerza. Recuérdese que Lázaro llega a buen puerto precisamente con fuerza y maña. Éste es el caso de Lázaro y lo es porque en esa sociedad la prosperidad está vinculada con lo material. Sin embargo, como cristiano el hombre debe estar, como ya se ha dicho, por encima de la fortuna. Este postulado, dice Vives no sin cierta ironía, será considerado herético sobre todo a la vista de un clero como el que se desparrama por el Lazarillo que también triunfa a golpe de fuerza sin reparar en que su maestro es Cristo. La paz y la tranquilidad a la que Vives aspira no puede ser otra que la de Cristo y no la que nace de una estabilidad material. En este sentido, explica la situación peligrosa y ridícula de los hombres como consecuencia del abandono de Cristo. Por tanto, no sólo Cristo es la solución, sino que el abandono de Cristo es lo que deja la vida humana en manos de la burla de la fortuna (Jiménez Delgado, 1978: 372-3):

El mismo que da los hijos cuidará de facilitar con qué alimentarlos. Nosotros no somos sino como ministros de ese cuidado o providencia con una gran conformidad de nuestro servicio, cuanto con más seguridad ponemos en Él nuestra esperanza. Y no podemos prepararles alimento más seguro, que contando con la justicia de Dios. Ya conoces aquellas dos sentencias: Jamás vi abandonado al justo y buscad primero el reino de Dios. Si así no lo hacemos, perdemos nuestro derecho y quedamos vencidos en la causa, como si actuáramos sin enterarnos de las leyes, acerca de lo cual se ha dicho lo siguiente: Cuando hubiéreis hecho todas estas cosas, decid: "Siervos inútiles somos".

Si hiciéramos la paz con Dios, fácilmente la paz habitaría entre los hombres; pero Él no quiere que vivamos en paz unos con otros, ya que estamos en guerra con Él. Lo que falta es que, ya que a nosotros nos tocó ser espectadores, nos figuremos estar viendo una tragedia, en la cual se nos ofrecen las desgracias de los demás como propio esparcimiento, algo así como a veces en las cosas muy amargas encontramos una cierta dulzura. Pero por lo que veo, nosotros de tal manera contemplamos la representación, como antiguamente en Roma aquellos contra los cuales los histriones lanzaban trozos de madera desde el escenario, para que no se marcharan libres de tragedia.

En consecuencia, frente al Lázaro que campea en esa lid contra la fortuna, Vives propone seguir a Cristo, porque sólo de esa manera los bienes y los males de fortuna son relativizados y se puede alcanzar una paz duradera que no dependa de la fungibilidad de lo material. Eso es lo que sucede en el Lazarillo: las desgracias son motivo de esparcimiento y todos los hombres luchan dialécticamente en una tragedia en la que Dios ha desaparecido. La desgracia tiene peso en la vida del hombre cuando éste cifra en las cosas el valor supremo. Este olvido de Dios empieza cuando el hombre se olvida que está en sus manos y busca su porvenir en otros sitios. Para Vives la vida está en manos de Dios y sólo en él hay que esperar (Jiménez Delgado, 1978: 421):

Muchos piden a los astros su buena suerte, como si no estuviera solamente en las manos de Dios. Sólo a Dios pertenece el conocimiento del porvenir. Buscarlo en otra parte es una notable propensión a la idolatría, y esto hace que, contentándonos con lo que vemos, poco a poco nos vayamos descuidando de Dios. 
Recuérdese lo dicho antes: para el valenciano la fortuna personal es lo que menos valor tiene en la persona. Así se lo dice a Erasmo refiriéndose a Budé, en el que destaca su genialidad por encima de su fortuna, y ello aunque Budé era persona de posibles (Jiménez Delgado 1978: 190):

¡Qué hombre ese, ya se mire su talento, ya su erudición, ya sus costumbres y, lo que en el hombre tiene menos valor, su fortuna! Esta, aunque en él es muy espléndida, es insignificante y sin brillo, si se la compara con la magnitud y la brillantez de sus demás prendas. (...) Por lo demás, no hay que valorarlo por esto, pues todas sus demás cualidades oscurecen la estrella de su fortuna y la de su linaje, lo mismo que el sol oscurece las estrellas.

En este caso la palabra fortuna alude a la situación económica desahogada y a la gloria que ofrendan las artes. Pero, úsese en el contexto que sea, para Vives la única manera de enfrentar la fortuna es superarla y no oponerse a ella ni tratar de tomarla por aliada, como hace Lázaro. Quien se le opone, se ve arrastrado por ella y quien trata de aprovecharse de ella sufre su burla. Este último sería el caso del citado Lázaro. El cristiano la deja a un lado y entiende que su libertad no reside en escapar de la fortuna, sino en vivir en el espíritu de Cristo ${ }^{6}$. Desde ese espíritu puede el hombre, como imitador de Cristo, procurar el bien común que nace de la concordia y al que vives pretendió contribuir con obras como De subventione pauperum ${ }^{7}$. En coherencia con estos pensamientos el único mal que realmente puede sufrir un hombre es estar alejado de Cristo. Es más, ese alejamiento es en ocasiones un castigo, ya que, como dice el valenciano en sus Meditaciones sobre los salmos, está con Dios aquel al que Cristo conduce (Riber 1992: I 301):

Cristo, que es nuestra vida, dice en su Evangelio que nadie puede ir a Él si Dios Padre y Señor de todo lo criado no le atrajere. Es, pues, verdad averiguada que esta gracia no es del que quiere o del que corre, sino de aquel a quien Dios se lo da por misericordia.

Desde esta óptica construye su idea de la providencia como superación del concepto de fortuna y como materialización de la virtud. Por eso afirma en Excitaciones del alma hacia Dios que Dios es el que colma todas las necesidades (Riber 1992: I 442):

Aquella naturaleza omnipotente y santa a quien llamamos Dios, nos arrebata con su grandeza a la admiración y con su bondad nos invita a su amor y nos obliga a la gratitud con los beneficios que nos hace cada día. Demás de esto, nuestro flaco natural y nuestras necesidades no ya cotidianas, sino de cada uno de los momentos, nos inducen a refugiarnos en Él, puesto caso que Él lo puede todo, dotado como está de una inmensa fuerza y poderío, y no hay cosa que no esperemos de sus bondad que tenemos tan experimentada.

Nolefaltaban a Vives testimonios escriturísticos para sostener estas afirmaciones. En sus palabras resuenan las de Cristo en el Sermón de la Montaña: "No seáis como ellos, pues vuestro Padre sabe lo que os hace falta antes de que lo pidáis" (Mt 6,8). Resuenan pasajes como el de la multiplicación de los panes (Mt 14,20) o fragmentos como el que escribe Lucas afirmando que Dios da testimonio de sí mismo con los

\footnotetext{
${ }^{6}$ 2Cor 3,17: Ahora bien, el Señor es el Espíritu; y donde está el Espíritu del Señor, hay libertad.

${ }^{7}$ Lc 4, 18s: El Espíritu del Señor está sobre mí, porque él me ha ungido. Me ha enviado a evangelizar a los pobres, a proclamar a los cautivos la libertad, y a los ciegos, la vista; a poner en libertad a los oprimidos; a proclamar el año de gracia del Señor.
} 
beneficios con los que cuida al hombre ${ }^{8}$. El valenciano considera en la misma obra anterior que todos los bienes proceden de Dios y que por ello hay que ser agradecido a la providencia y no a la fortuna (Riber 1992: I 447):

Puesto caso que de Dios proceden todos los bienes y que de ningún otro lado proceden, cuando hicieres algo de bueno levántate a recordar la procedencia de aquel bien y agradécelo a quien se dignó darte fuerzas para bien obrar. Si así no lo hicieres, serás tenido por descuidado del beneficio y, por ende, ingrato.

Lázaro de Tormes hace lo contrario: cree que su nuevo estatus proviene de su maña y fuerza. Vives, como ya hemos dicho, muestra en esta obra las consecuencias de una sociedad sin providencia, y lo hace, como también se comentó al principio de este trabajo, siendo él una víctima de la fortuna más infausta. Pero Vives se sostiene con la esperanza en su Cristo ${ }^{9}$, porque asegura que quien construye es la providencia ${ }^{10}$. En esta línea argumental tiene todo su sentido que el humanista afirme en Escolta del alma que la virtud es más poderosa que la fortuna (Riber 1992: I 1179s):

8. Virtus, citra fortunam valida. (Más poderosa es la virtud que la fortuna)

Esta sentencia es estoica, pero con mejor razón cristiana.

9. Tibicen fortunae, virtus. (La virtud es el poste o sostén de la fortuna)

Flacos son sin la virtud todos los accidentes exteriores que sobrevienen al cuerpo; por eso el sustentáculo de la fortuna es la virtud, pues ésta es el poste en los edificios.

Obsérvese que no se trata de la virtud maquiavélica que puedellegar a sobrepujar la fortuna gracias a la maña y la fuerza, sino que la virtud en Vives es la conciencia de probidad y de justicia en la actuación. Dicho esto se entiende que tenga a la fortuna como una herramienta frente a la fortuna (Riber 1992: I 1183):

45. Virtus exercetur, non perit (La virtud se ejercita, pero no perece).

46. Generosa virtus, flatu accenditur (La virtud generosa enciéndese con un soplo).

47: Virtus inimicitiis fortunae crescit (La virtud se crece con las ofensivas de la fortuna)

Estos tres adagios vienen a significar lo mismo: la virtud se agiganta con las adversidades. El segundo aforismo puede referirse al soplo de la fortuna airada o al céfiro blando de la lisonja.

En la virtud se encuentra, por tanto, la preferencia por una vida con adversidades y dichas tal y como Vives comentaba con la reina Catalina. La virtud supera la fortuna no porque se alíe con ella o porque la aherroje sino porque la virtud es el comedimiento y la mesura que el hombre adquiere a través de los derroteros ambivalentes de la vida. Esa virtud no es que sea ajena a la virtù maquiavélica, sino que es completamente contraria (Riber 1992: I 1187):

\footnotetext{
${ }^{8}$ Hch 14, 17: aunque no ha dejado de dar testimonio de sí mismo con sus beneficios, mandándoos desde el cielo la lluvia y las cosechas a sus tiempos, dándoos comida y alegría en abundancia.

${ }^{9}$ Lc 21,16-9: Y hasta vuestros padres, y parientes, y hermanos, y amigos os entregarán, y matarán a algunos de vosotros, y todos os odiarán a causa de mi nombre. Pero ni un cabello de vuestra cabeza perecerá; con vuestra perseverancia salvaréis vuestras almas.
}

${ }^{10}$ Sal 127, 1: Si el Señor no construye la casa, en vano se cansan los albañiles; si el Señor no guarda la ciudad, en vano vigilan los centinelas. 
73 Vicit vim virtus (La virtud triunfó de la fuerza).

La virtud, como próxima a Dios, quebranta todas las fuerzas de los hombres.

74: Stravit fortunam virtus (La virtud derribó al suelo a la fortuna).

Con muchos ejemplos se ha demostrado que la virtud es más poderosa que las riquezas, que las contingencias fortuitas, por maneras que hubo varones grandes y descollados en virtud, que con sublime intrepidez, pusieron bajo sus pies todos los azares humanos y su virtud los superó, como Sócrates superó la cárcel, Rutilio el destierro, la enemistad de los poderosos Catón y tormentos los más atroces nuestros mártires.

75 Fortitudo in fortunam, non homines (Reciedumbre contra la fortuna, no contra los hombres)

No es fortaleza herir, derribar, causar mortandad a hierro en los hombres; esto es cosa de fieras, no de hombres. La fortaleza auténtica consiste en cohibir los vicios, desdeñar lo fortuito, no temer la pérdida de ninguna cosa, sino de la virtud.

No requieren glosa estas palabras, porque en ella se sintetizan los principales postulados de Vives sobre la fortuna. Aquellas circunstancias que carecen de causa final no son más que recursos de la providencia para probar al hombre en la virtud. No es este argumento lejano al de Séneca, aunque ciertamente cristianizado. La virtud es ese elemento estable que Vives buscaba para justificar la existencia humana. Ante la inestabilidad de todo lo material, la virtud es el ancla que sitúa al hombre en lo estable y perenne (Riber 1992: I 1192):

117. Quod commodavit fortuna tollet (lo que te dio la fortuna, te lo quitará)

118. Quod mutuavit Natura, repetet (Lo que te prestó la Naturaleza, te lo reclamará)

119. Quod paraverit virtus, retinebis (Lo que la virtud te granjeare, eso lo retendrás)

Dadas en préstamo por la fortuna son aquellas cosas que a la fortuna se devuelven en su mismo estado. Prestadas por la Naturaleza son aquellas cosas que se le devuelven, semejantes, sí, pero no las mismas. Unas y otras no han de estar en nuestro poder más tiempo del que consintieren el acreedor o el prestamista. Mas las gloriosas hazañas de la virtud, como dice Salustio, son imperecederas, como lo es el alma misma

La virtud se materializa en un esfuerzo por beneficiar a los demás como se dice en el aforismo 149 de Escolta del alma (Riber 1992: I 1195). Otros rasgos son no vivir para las riquezas, sino darles exclusivamente el valor de uso. Lo que se puede perder no puede constituir la finalidad de la vida. Así habla en el aforismo 153 de esta misma obra (Riber 1992: I 1196). Y en el terreno propiamente político asegurará que sólo la virtud mantiene el poder. Parece que con esta afirmación contradice conscientemente el pensar de Maquiavelo (Riber 1992: I 1200):

189. Linguas ne praecide sed cave (No cortes lenguas, pero guárdate de ellas).

No se ha de quitar la libertad a los hombres, pues como dice Augusto: Está bien que en las ciudades libres sean las lenguas libres. Pero has de vivir de tal manera, que los hombres no han de sentir la tentación de ejercer contra ti su libertad.

190. Ora virtute obtura non metu (Cierra las bocas con la virtud, no con el miedo).

Tiene la misma aplicación práctica. No ha de cerrar las bocas el miedo, que es un cerrojo harto endeble y frágil. Obrando bien conseguirás que nadie sienta mal de ti y, por tanto, que no lo diga. 
En definitiva, el fin de la vida humana es Cristo; Cristo es su rector y a su voluntad -a su providencia- se someten todas las contingencias de la fortuna (Riber 1992: I 1204):

213: Unum est necessarium (Una sola cosa es necesaria).

Palabras son éstas de Jesucristo, Salvador nuestro, para avivar el fervor de la piedad y disminuir la solicitud de las cosas perecederas: la procuración de la comida y de la bebida y del gobierno doméstico, en la cual Marta andaba metida, es cosa ciertamente útil al hombre, a su debido tiempo; pero sentarse a los pies de Jesús y beber su palabra con pureza del alma, que era el oficio de Magdalena, es lo necesario, en definitiva, y que no le será quitado jamás por jamás. Cuando hubieres apurado todos los recursos del ingenio todo lo que lo adorna y lo decora, todo lo que compone y adereza el cuerpo, todas las comodidades exteriores, entenderás que sola esta cosa es necesaria.

\section{Mente Deo defixus (Con tu mente clavada en Dios)}

Este será el último de lo símbolos, puesto aquí con agüero tan feliz, como aquel primero que pusimos: Scopus vitae Christus. Él es el principio; Él es el fin. De Él parten todas las cosa; todas las cosas tienden a Él. En Él es menester que nos ahinquemos si queremos ser felices, no con otro clavo que el de nuestra mente. Muchos otros símbolos y empresas pueden sacarse de Platón, de Cicerón, de Séneca, de Horacio, pero, singularmente, de las Sagradas Letras, manantial tan copioso como puro. En los autores cristianos hállanse tantos proverbios, metáforas, alegorías, apólogos también y anécdotas, que pueden proporcionárnoslos en número muy grande. Y aun a los que yo puse aquí se les puede cambiar y darles otro giro, y de los escolios sacar otros y otros. Por ello no puse los que andan en boca de todos: Conócete a ti mismo; De nada, demasiado; Promete, la suerte está echada, que dícense ser los tres oráculos de Apolo, y La mitad es más que el todo, que es de Hesíodo, y el Sontente y abstente, que es de Epicteto. Los que puse bastarán, bien para la abundancia de las sentencias, que casi todas están en ellos incluidas, sino como demostración de que pueden formularse una infinidad.

Conocerse a sí mismo no es otra cosa que encontrar un punto estable para sostener la vida anteponiendo el bien común al lucro personal. En la virtù de Maquiavelo no existe esa noción de estabilidad, como tampoco existe en Lázaro de Tormes. Sí existe en el Pompeyo que escapa de la derrota con la conciencia de haber aprovechado la fortuna en pro de su ciudad y de aceptar la derrota como contingencia irrefrenable. Vives propone a la consideración de los lectores un Pompeyo cristiano que sabe que en la providencia hay descanso y consuelo ${ }^{11}$; que es la providencia la que hace prosperar los proyectos ${ }^{12}$; que la providencia enseña el valor real de las cosas del mundo ${ }^{13}$. En el concepto de providencia subsume Vives la idea filosófica de la fortuna como circunstancias que carecen de causa final y, al mismo tiempo, el concepto más popular que transfiere a la fortuna la razón de la prosperidad y la adversidad.

\footnotetext{
${ }^{11} \mathrm{Mt} 10,28 \mathrm{~s}$ : Venid a mí todos los que estáis cansados y agobiados, y yo os aliviaré. Tomad mi yugo sobre vosotros y aprended de mí, que soy manso y humilde de corazón, y encontraréis descanso para vuestras almas.

${ }^{12}$ 1Cor3,6s: Yo planté, Apolo regó, pero fue Dios quien hizo crecer; de modo que, ni el que planta es nada, ni tampoco el que riega; sino Dios, que hace crecer.

${ }^{13} 1$ Tim 6,17-9: A los ricos de este mundo ordénales que no sean altaneros ni pongan su esperanza en la incertidumbre de la riqueza, sino en Dios que nos provee de todo en abundancia para que lo disfrutemos; que hagan el bien, sean ricos en buenas obras, generosos y dispuestos a compartir; y así atesorarán un excelente fondo para el porvenir y alcanzarán aquella que es realmente la vida verdadera.
} 


\section{BIBLIOGRAFÍA}

Calero, F.(2006): Juan Luis Vives, autor del Lazarillo de Tormes, Valencia, Ajuntament.

Chabod, F. (1984): Escritos sobre Maquiavelo, México D. F., FCE.

Conde, F.J. (2003): El saber político en Maquiavelo, Madrid, Biblioteca de la Revista de Occidente. [reimpr. B. Aires 2003].

Dotti, U. (2003): Machiavelli rivoluzionario, Roma, Carocci.

Fernández Santamaría, J.A. (1990): Juan Luis Vives: Escepticismo y prudencia en el renacimiento, Salamanca, Universidad.

García, A. (1987): Els Vives: una família de jueus valencians, València, Eliseu Climent.

Garin, E. (1993): Machiavelli fra politica e storia, Torino, Einaudi.

Gramsci, A. (1949): Note sul Machiavelli, sulla politica e sullo stato moderno, Torino, Einaudi. [Notas sobre Maquiavelo, sobre la politica y sobre el estado moderno. B. Aires, Nueva Visión.

Hörnqvist, M. (2004): Machiavelli and Empire, Cambridge, Cambridge UP.

Jiménez Delgado, J. (1978): Epistolario, Madrid, Editora Nacional.

Lazarillo de Tormes (2006): Edición de F. Rico, Barcelona, Cátedra.

Machiavelli, N. (1966): Il principe. Discorsi sopra la prima deca di Tito Livio, Novara, Istituto Geografico de Agostini.

Machiavelli, N. (2000): Discorsi sopra la prima deca di Tito Livio, seguiti dalle Considerazioni intorno ai Discorsi del Machiavelli di Francesco Guicciardini, Torino, Einaudi.

Otón Sobrino, E. (2000): “Del azar y de la necesidad en Lucrecio”, Cuadernos de Filología Italiana, número extraordinario, 45-50.

Pinta Llorente, M. de la - De Palacio y de Palacio, J.M. (eds.) (1964ss): Procesos inquisitoriales contra la familia judia de Juan Luis Vives, Madrid, Instituto Arias Montano.

Riber, L. (1992): Obras completas de J.L. Vives. Vol. I: Meditaciones sobre los salmos, 291364; Excitaciones del alma hacia Dios, 441-58; Pompeius fugiens, 581-94; Escolta del alma, 1177-204. Valencia, Generalitat (reimpr.).

Russo, L. (1988): Machiavelli, Roma-Bari, Laterza.

Séneca (2000): Sobre la providencia. En: Diálogos, intr. trad. y notas de Mariné Isidro, J., Madrid, Gredos, 63-90.

Skinner, K. (1981): Machiavelli, Oxford, Oxford UP. [Trad. española: Maquiavelo. Madrid, Alianza, 1995].

Veyne, P. (1995): Séneca y el estoicismo, trad. de M. Utrilla, México, FCE.

Vives, J.L. (1978): Epistolario, Vid. Jiménez Delgado, J.

Vives, J.L. (1992): Escolata del alma, Vid. Riber, L.

Vives, J.L. (1992): Excitaciones del alma hacia Dios, Vid. Riber, L.

Vives, J.L. (1992): Meditaciones sobre los salmos, Vid. Riber, L. 
Vives, J.L. (1992): Pompeius fugiens, Vid. Riber, L.

Vives, J.L. (1992): Sobre las disensiones en Europa y la guerra contra los turcos, en De Europae dissidiis et república, trad. de Calero, F. y Echarte, M. J. Valencia. Ajuntament.

Vives, J.L. (1997): De concordia et discordia in humano genere, intr. de Nero, V. del, trad. de Calero, F., Arribas. M. L. y Usábel, P., Valencia, Ajuntament.

Vives, J.L. (2000): Los comentarios a la Ciudad de Dios de san Agustín, trad. de R. Cabrera Petit. Valencia, Ajuntament. [Esta edición incluye la traducción de la obra agustiniana en traducción de S. Santamarta del Río y M. Fuertes Lanero (BAC, 2009 reimpr.)].

Vives, J.L. (2009): Diálogo de doctrina Christiana, introducción, edición y notas de Calero, F. y Coronel Ramos, M. A., Madrid, BAC-UNED. 